\title{
ANALISIS AKUMULASI KANDUNGAN LOGAM KADMIUM PADA AKAR DAN DAUN MANGROVE DI PERAIRAN BASAAN-BELANG KABUPATEN MINAHASA TENGGARA DAN LIKUPANG KABUPATEN MINAHASA UTARA
}

\author{
(The Analysis of Cadmium Accumulation in The Roots and Leaves of Mangrove in The \\ Waters of Basaan-Belang Southeastern Minahasa Regency and Likupang North \\ Minahasa Regency)
}

\section{Nikita R. Kawung ${ }^{1 \star}$, Rizald R. Rompas ${ }^{1}$, James J.H. Paulus ${ }^{1}$, Markus T. Lasut, Desy H.M. Mantiri ${ }^{1}$, Natalie D. Rumampuk ${ }^{1}$}

1. Program Studi IImu Kelautan, Fakultas Perikanan dan IImu Kelautan, Universitas Sam Ratulangi, Manado.

*e-mail : ribkanikitakawung@gmail.com

Ocean was very useful for cultivation activity, fishing, recreation, transportation and so on. But ocean also became the last alternative that accept load from those antrophogenic activities. Cadmium is one of the most dangerous heavy metals. When cadmium entering the aquatic ecosystem, it will be accumulated with the biota that can influence the food chain and become a big warning for human health who often exploit the marine resources. The goal of this study is to analyze the cadmium content in mangrove roots and leaves of Avicennia sp. and Rhizophora sp. in the different locations. The analysis result of cadmium from two mangrove species in four different sampling location of this research, the highest one found in Rhizophora sp. from Ambon village in Likupang that is $26.742 \mathrm{ppb}$ in leaves and $21.027 \mathrm{ppb}$ in roots, while the lowest content with number $<0.07 \mathrm{ppb}$ found in roots from Buku village in Belang and $14.346 \mathrm{ppb}$ in leaves from Laboratory of Faculty of Fisheries and Marine Science Likupang Two village. Then the highest cadmium in Avicennia sp. found in roots, that is $44.355 \mathrm{ppb}$ from Ambon village in Likupang and $23.164 \mathrm{ppb}$ in leaves from Laboratory of Faculty of Fisheries and Marine Science Likupang Two village, while the lowest content was found in Basaan Village, that is $22.234 \mathrm{ppb}$ in roots and $8.741 \mathrm{ppb}$ in leaves. The difference of cadmium accumulation in two species of mangrove caused by the differences of roots and leaves morphology. Avicennia $\mathrm{sp}$. can be useful as a fitoremediator plant because it has a greater power for metal absorptions than Rhizophora sp.

Keywords: Heavy metal, Cadmium (Cd), Mangrove, Roots, Leaves

Laut sangat bermanfaat dalam kegiatan budidaya, penangkapan ikan, rekreasi, transportasi dan sebagainya. Tapi laut juga menjadi alternatif terakhir yang menerima beban dari aktivitas-aktivitas antropogenik tersebut. Kadmium adalah salah satu logam berat yang paling berbahaya. Ketika kadmium memasuki ekosistem akuatik, kadmium akan terakumulasi dengan biota laut dan mempengaruhi rantai makanan sehingga mengancam kesehatan manusia yang sering mengeksploitasi sumber daya laut. Tujuan dari penelitian ini adalah untuk menganalisis kandungan kadmium di akar dan daun mangrove Avicennia sp. dan Rhizophora sp. pada lokasi yang berbeda. Hasil analisis kadmium dari dua spesies mangrove di empat lokasi sampling yang berbeda dari penelitian ini, yang tertinggi pada Rhizophora sp. ditemukan di daun yaitu $26.742 \mathrm{ppb}$ dan $21.027 \mathrm{ppb}$ di akar dari Desa Ambon di Likupang, sedangkan kandungan terendah berjumlah $<0,07$ ppb ditemukan di akar dari Desa Buku di Belang dan 14.346 ppb di daun dari Laboratorium Fakultas Perikanan dan IImu Kelautan Desa Likupang Dua. Kemudian kandungan kadmium tertinggi pada Avicennia sp. ditemukan di akar yaitu 44.355 ppb dari Desa Ambon di Likupang dan 23.164 ppb di daun dari Laboratorium Fakultas Perikanan dan IImu Kelautan Desa Likupang Dua, sedangkan kandungan terendah ditemukan di Desa Basaan, yaitu $22.234 \mathrm{ppb}$ di akar dan $8.741 \mathrm{ppb}$ di daun. Perbedaan akumulasi kadmium pada dua spesies mangrove disebabkan adanya perbedaan morfologi akar dan daun. Mangrove jenis Avicennia sp. dapat dijadikan sebagai tumbuhan fitoremediator karena memiliki daya serap logam kadmium lebih besar dibandingkan Rhizophora sp.

Kata kunci: Logam Berat, Kadmium (Cd), Mangrove, Akar, Daun 


\section{PENDAHULUAN}

Pencemaran merupakan perubahan kondisi air yang tidak menguntungkan karena kehadiran bahan pencemar dari kegiatan antropogenik yang berasal dari daratan melalui air sungai yang telah tercemar dengan logam berat. Logam berat adalah salah satu bahan pencemar lingkungan yang sangat berbahaya yang diakibatkan oleh pertambangan, maupun kegiatan pabrik-pabrik yang menjadikan logam sebagai bahan utama dalam kegiatan tersebut, yang terbawa hingga ke laut dan menyebabkan pencemaran.

Tingginya tekanan lingkungan pada ekosistem pantai disebabkan adanya buangan dari berbagai aktivitas manusia di daratan yang dapat mengalir ke laut melalui sungai (Kawung, et.al, 2016). Buangan-buangan tersebut dapat berupa bahan anorganik ataupun organik. Bahan anorganik dapat berupa logam-logam, terutama hasil buangan pertambangan, transportasi dan industri yang bersifat toksik (Tilaar, 2014). Sumber pasokan alamiah bahan anorganik seperti logam kadmium dapat berasal dari aktifitas vulkanik gunung berapi (Rompas, 2010; Paulus, 2017).

Logam berat yang masuk keperairan dalam bentuk terlarut, akan terakumulasi pada organisme perairan seperti mikroalga serta pada tumbuhan mangrove. Mangrove merupakan salah satu ekosistem pesisir yang unik dan terdapat hampir di seluruh pantai pulaupulau Indonesia (Paruntu et.al, 2017). Logam berat yang terakumulasi pada sedimen selanjutnya diabsorpsi melalui sistem perakaran mangrove, tersimpan pada batang dan juga mengalami penguraian dalam sistem respirasi tumbuhan dengan melepaskan logam ke atmosfir (Paulus, 2017). Ekosistem mangrove adalah salah satu ekosistem yang unik, karena berada pada daerah peralihan antara ekosistem darat dan laut (Parvaresh, et.al., 2010). Ekosistem mangrove juga mampu menstabilkan zona pantai dari erosi serta bertindak sebagai zona penyangga antara darat dan laut (Prasad dan Ramanathan, 2008).

Kadmium merupakan salah satu logam berat yang dihasilkan secara alami maupun antropogenik. Kegiatan pertambangan akan menghasilkan kadmium, contohnya kegiatan pertambangan emas yang dilakukan dengan cara menggali, sehingga logamlogam lain yang berada di tanah akan ikut terserap dan menimbulkan pencemaran dilingkungan. Diketahui bahwa kadmium digunakan dalam industri, antara lain dipakai sebagai pelapis elektrik karena berkemampuan sebagai bahan anti korosi (anti karat). Kadmium mudah berikatan dengan klor dan memiliki valensi $2^{+}$, sehingga mudah berikatan dengan garam-garam dilaut membentuk kadmium ionik. Bentuk garam kadmium banyak digunakan dalam pembuatan gelas dan campuran perak, produksi foto-elektrik, foto konduktor dan fosforus. Kadmium dalam bentuk asetat banyak digunakan sebagai campuran pada industri porselen dan keramik (Rompas, 2010).

Logam kadmium $(\mathrm{Cd})$ merupakan elemen toksik yang dapat berpengaruh pada sistim ekologi perairan sehingga dikelompokan sebagai limah B3 (bahan berbahaya dan beracun). Keracunan kadmium dalam waktu lama dapat membahayakan kesehatan paru-paru, tulang, hati, ginjal, kelenjar reproduksi, berefek pada otak dan menyebabkan tekanan darah tinggi. Logam ini juga bersifat neurotoksin yang menimbulkan dampak kerusakan indera penciuman (Petrucci, 1987). Penyakit melunaknya tulang yang umumnya diakibatkan kurangnya vitamin $D$ sebagai akibat yang ditimbulkan oleh logam kadmium sehingga terjadi gangguan daya keseimbangan kandungan kalsium dan fosfat dalam ginjal yang dikenal dengan nama osteomalasea atau penyakit "Itaiitai Byo" (Atdjas, 2008).

Kadmium dalam tubuh akan terakumulasi dalam hati dan terikat 
sebagai metalotionein mengandung unsur sistein. Kadmium terikat dalam gugus sufhidril (-SH) dalam enzim seperti karboksil sisteinil, histidil, hidroksil, dan fosfatil dari protein purin. Kemungkinan besar pengaruh toksisitas kadmium (Cd) disebabkan oleh interaksi antara kadmium (Cd) dan protein tersebut, sehingga menimbulkan hambatan terhadap aktivitas kerja enzim dalam tubuh (Darmono, 2001).

Kehadiran kadmium di perairan dapat mengancam keseimbangan ekologi dan kelangsungan hidup organisme di perairan tersebut (Mamoribo, et.al., 2015). Penelitian ini bertujuan menganalisis kandungan logam kadmium (Cd) pada akar dan daun mangrove Avicennia sp. dan Rhizophora sp. dan mengetahu perbedaan kandungan logam kadmium (Cd) pada akar dan daun mangrove di daerah Basaan, Belang dan di Likupang.

\section{METODE PENELITIAN}

Pengambilan sampling akar dan daun mangrove Avicennia sp. dan Rhizophora sp. berada di 4 lokasi berbeda, yaitu di Minahasa Tenggara di Basaan dan desa Buku Belang dan Minahasa Utara di perairan Likupang di Laboratorium Basah Fakultas Perikanan dan IImu Kelautan Universitas Sam Ratulangi di Desa Likupang Dua dan Desa Ambon.

\section{Preparasi Sampel}

Sampel dikering anginkan dalam ruangan dan dihaluskan. Kemudian sampel di destruksi basah dengan cara ditimbang sebanyak $0,5 \mathrm{gr}$ sampel dan diletakkan didalam vessel (m), ditambahkan Asam Nitrat $\left(\mathrm{HNO}_{3}\right)$ pekat

Keterangan:

$\mathrm{R}=$ Konsentrasi larutan sampel (ppb)

$\mathrm{V}=$ Volume akhir $(\mathrm{ml})$

$\mathrm{m}=$ Berat sampel $(\mathrm{g})$
$65 \%$ sebanyak $10 \mathrm{ml}$, Vessel dibiarkan bereaksi dengan keadaan terbuka selama 30 menit. Kemudian Vessel ditutup dan dimasukkan kedalam microwave digester selanjutnya di set kondisi microwave untuk reaksi destruksi. Setelah rekasi selesai, larutan destruksi dipindahkan dari vessel ke labu ukur $25 \mathrm{ml}$ (V) dan ditepatkan menggunakan aquabidest sampai tanda batas untuk dianalisis kandungan kadmium.

\section{Pembuatan Larutan Standar Kadmium 2, 4 dan 8 ppb}

Larutan Cd 1000 ppm dipipet sebanyak $100 \mu$ l kedalam labu ukur 100 $\mathrm{ml}$ dan ditepatkan dengan aquabidest untuk menghasilkan larutan Cd 1000 ppb. Kemudian larutan Cd 1000 ppb dipipet sebanyak 100, 200, dan $400 \mu \mathrm{l}$ menggunakan mikropipet kedalam labu ukur $100 \mathrm{ml}$ dan ditepatkan dengan aquabidest untuk menghasilkan larutan Cd 2, 4 dan 8 ppb.

\section{Pengukuran Kandungan Kadmium}

Pengukuran absorbansi larutan standar dan sampel menggunakan spektrofotometer serapan atom metode Graphite Furnace (R) dengan panjangan gelombang 228,8 nm. Absorbansi larutan standar diukur dengan konsentrasi $0,2,4$, dan 8 ppb. Selanjutnya pengukuran absorbansi kandungan kadmium pada sampel akar dan daun mangrove hasil destruksi. Hasil perhitungan konsentrasi kadmium dalam sampel menggunakan rumus

$$
\text { C : } C d=\frac{R x V}{m}
$$




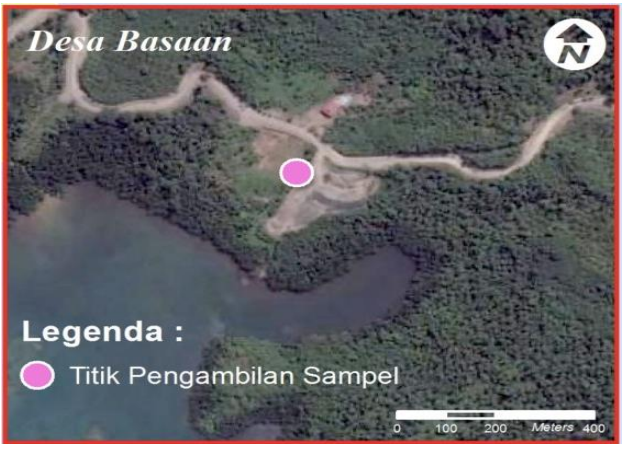

Gambar 3. peta lokasi pengambilan sampel di Desa Basaan.

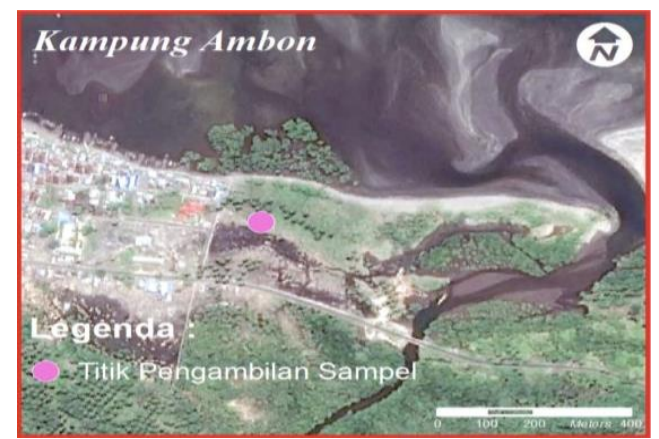

Gambar 5. Peta lokasi pengambilan sampel.

\section{HASIL DAN PEMBAHASAN}

Hasil analisis kandungan logam kadmium pada Rhizophora sp. di Desa Basaan dibagian akar adalah 20.966 ppb, dan dibagian daun 20.773 ppb. Sedangkan logam kadmium pada Avicennia sp. dibagian akar 22.234 ppb dan dibagian daun 8.471 ppb jauh lebih kecil di bagian daun Rizhophora sp. Kandungan logam kadmium di lokasi Desa Buku Kecamatan Belang menunjukkan dibagian akar $<0.07$ ppb. Kandungan logam kadmium pada akar Rhizophora sp. ini merupakan kandungan logam yang paling kecil dari semua nilai pengamatan sedangkan dibagian daun 16.163 ppb. Selanjutnya kandungan logam kadmium dibagian akar Avicennia sp. 30.563 ppb sedangkan dibagian daun 14.704 ppb.

Penyerapan logam kadmium dari akar Rhizophora sp. di Lab Basah FPIK desa Likupang Dua adalah 16.543 ppb

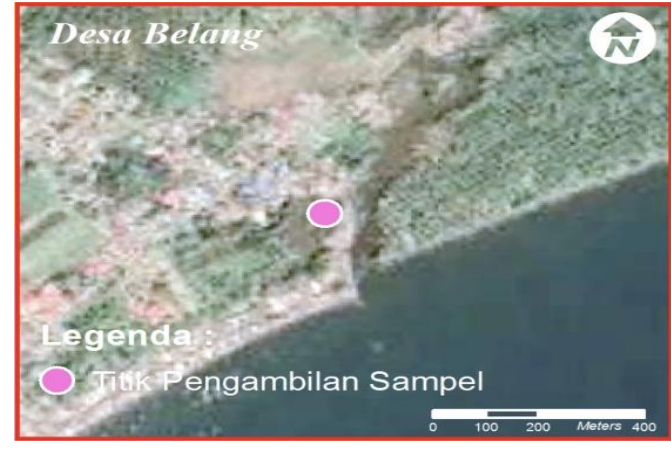

Gambar 4. Peta lokasi pengambilan sampel di Desa Buku Belang.

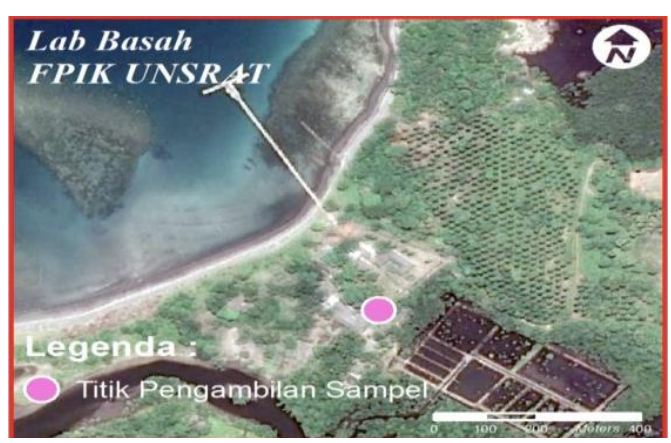

Gambar 6. Peta lokasi pengambilan sampel di lab basah FPIK Desa Likupang Dua.

yang memiliki perbedaan kecil dengan bagian daun yaitu $14.346 \mathrm{ppb}$, sama halnya dengan logam kadmium pada akar dan daun Avicennia sp. yang tidak jauh berbeda yaitu 23.496 ppb dan 23.164 ppb.

Kandungan kadmium dibagian akar Rhizophora sp. yang berada di Desa Ambon Likupang, sebesar 21.027 ppb dan dibagian daun 26.742 ppb. Akumulasi dibagian akar Rhizophora sp. memiliki perbedaan dua kali lebih kecil dibandingkan akumulasi logam kadmium dibagian akar Avicennia sp. yaitu sebesar 44.355 ppb, namun akumulasi

logam kadmium dibagian daun Avicennia sp.12.517 ppb, lebih kecil dibandinhkan dibagian daun Rhizophora sp. yaitu 26.742 ppb.

Kandungan logam kadmium lebih banyak terakumulasi pada akar untuk Desa Basaan dan Lab Basah FPIK desa Likupang Dua dari mangrove jenis 
Rhizophora sp. sedangkan di Desa Buku Belang dan Desa Ambon Likupang lebih banyak terakumulasi dibagian daun. Hal ini kemungkinan pada saat pengambilan sampel proses distribusi logam kadmium sudah terangkut ke bagian daun bersamasama dengan nutrien yang diabsorbsi oleh akar menuju ke daun.

Akumulasi logam terbanyak terdapat di akar untuk sampel Rhizophora sp. Desa Basaan dan Lab Basah FPIK di desa Likupang Dua sedangkan di desa Buku Belang dan desa Ambon Likupang akumulasi terbanyak terdapat di daun. Berbeda dengan mangrove jenis Avicennia sp. dimana dari empat lokasi yang dijadikan tempat pengambilan sampel akumulasi logam kadmium terbanyak pada akar. Perbedaan daya absorbsi logam kadmium dari dua jenis mangrove lebih besar pada jenis Avicennia sp.

Ada perbedaan daya akumulasi kadmium pada Rhizophora sp. dilokasi pengambilan sampel kemungkinan disebabkan aktivitas fisiologis dari tumbuhan mangrove yang dipengaruhi oleh lingkungan selain itu juga ketersediaan logam dalam sedimen. Hardiani (2009) menyatakan tumbuhan melakukan penyerapan logam oleh akar baik yang berasal dari sedimen maupun air kemudian terjadi translokasi ke bagian organ tumbuhan atau penimbunan pada jaringan tertentu. Menurut Saepulloh et al. (1995) yang disetir oleh Kristanti et.al., (2007) kemampuan tumbuh-tumbuhan mengambil sejumlah logam berat sangat ditentukan oleh ketersediaannya dalam lingkungan.

Kemungkinan lain perbedaan akumulasi logam pada bagian tumbuhan dimana pada saat pengambilan sampel proses distribusi logam kadmium sudah terangkut ke bagian daun bersama-sama dengan nutrien yang diabsorbsi oleh akar menuju ke daun. Deri dan La Ode (2013) menyatakan logam akan ditranslokasikan ke jaringan lainnya seperti batang dan daun. Menurut Kristanti, et.al., (2007) logam yang masuk kedalam tumbuhan tergantung daya serap (absorbansi) akar. Akar tumbuhan di dalam tanah menyerap ion dari media yang tidak hanya mengandung logam tertentu tetapi banyak ion unsur hara yang non esensial dan senyawa organik. Pola pergerakan logam yang masuk dalam tubuh tumbuhan sangat tergantung pada sifat logam yang ditranslokasikan ke bagian organ tumbuhan. Menurut Lakitan (2000) kemudahan suatu ion untuk ditranslokasikan ke bagian organ tumbuhan tergantung pada solubilitas (kelarutan) dari unsur kimia tersebut. Lebih lanjut dikatakan oleh Lakitan (2000) bahwa serapan ion tersebut menembus membran sel sangat ditentukan oleh kelarutan ion tersebut dalam lemak.

Tingginya kandungan logam di bagian akar menunjukan bahwa akar Avicennia sp. cenderung mengakumulasi logam dibagian akar, hal ini karena Avicennia sp. menancapkan akarnya ke sedimen secara utuh sehingga logam-logam yang ada terabsorbsi lebih banyak ke akar. Akar Avicennia sp. juga melalui sistem perakarannya yang menghujam ke tanah dan menyebar luas sehingga penyerapan logam lebih banyak.

Menurut Deri dan La Ode (2013) berdasarkan mekanisme fisiologis mengrove secara aktif melakukan penyerapan logam berat ketika konsentrasi logam berat di sedimen tinggi dan terakumulasi di akar. Selain itu terdapat sel endodermis pada akar yang menjadi penyaring dalam proses penyerapan logam berat. Adanya variasi kandungan logam pada dua jenis mangrove pada empat lokasi pengambilan sampel selain jenis tumbuhan hal ini juga dipengaruhi oleh kondisi lingkungan. Berdasarkan data diperoleh kandungan logam tertinggi terdapat di Minahasa Utara yaitu di Desa Ambon Likupang dengan konsetrasi $44.355 \mathrm{ppb}$. Hal ini disebabkan karena perbedaaan 
tekanan antropogenik yang mensuplai limbah serta bahan buangan yang masuk di daerah ekosistem mangrove. Selain itu kegiatan pertambangan batu bara yang berada di sekitar perairan Likupang menjadi salah satu faktor tingginya kandungan logam di Likupang baik di Lab Basah FPIK desa Likupang Dua maupun di Desa Ambon Likupang.

Perbedaan penyerapan

kandungan logam kadmium dari kedua jenis mangrove ini juga dikarenakan beberapa hal, seperti berbedanya ukuran pohon dari Rhizophora sp. dan Avicennia sp. dimana ukuran pohon Rhizophora sp. relatif lebih besar dibandingkan dengan pohon Avicennia sp. sehingga kemampuan menyerap logam dari dua jenis mangrove ini berbeda. Sistem perakaran juga mempengaruhi penyerapan kandungan logam antara Rhizophora sp. dan Avicennia sp. Jenis akar Rhizophora sp. adalah akar tunjang yang seperti cabang-cabang, sedangkan Avicennia sp. memiliki akar pasak/akar napas (Pneumatophores). Sistem perakaran yang dimiliki oleh Avicennia sp. lebih potensial dalam menyerap logam. Menurut Purwiyanto (2013) perbedaan akumulasi logam berat pada berbagai jenis mangrove selain disebabkan oleh perbedaan posisi tempat tumbuh, juga disebabkan oleh perbedaan jenis akar pada setiap jenis mangrove. Lebih lanjut, dikatakan oleh Jupriyati, et.al., (2013) bahwa jaringan akar Avicennia sp. mampu menghadapi cekaman logam berat pada lingkungannya, membentuk suatu zat kelat yang disebut fitokelatin. Fitokelatin merupakan suatu protein yang mampu mengikat logam yang tersusun dari beberapa asam amino seperti sistein dan glisin. Sehingga, kemampuan menyerap logam dari mangrove Avicennia sp. lebih besar dibandingkan Rhizophora sp.

Selain bentuk ukuran pohon dan sistem perakaran yang berbeda, letak dari kedua mangrove ini juga mempengaruhi perbedaan penyerapan kandungan logam kadmium, dimana
Avicennia sp. berada tepat di pinggir muara, mendapat masukkan logam pertama secara langsung, baik dari sedimen maupun kolom air. Hal tersebut mengakibatkan Avicennia sp. akan terlebih dahulu mengakumulasi logam yang masuk di ekosistem mangrove, sedangkan Rhizophora sp. berada di belakang Avicennia sp. yang mendapat masukkan logam hasil dari penyaringan Avicennia sp., sehingga konsentrasi logam yang diserap oleh akar dan daun Rhizophora sp. lebih sedikit dibandingkan Avicennia sp. (Purwiyanto, 2013).

Kristanti, et .al. (2007) menyatakan kandungan logam yang tinggi dalam akar mencerminkan upaya tumbuhan untuk mengatasi kelebihan ion yang dapat bersifat toksik melalui cara ekskresi, dimana ion tersebut dialirkan melalui jaringan floem ke akar dan dikeluarkan kembali ke dalam tanah. Menurut Yeo, et. al. (1977) dalam Kristanti, et. al., (2007) bahwa ion toksik secara aktif ditarik oleh jaringan xilem kemudian dieksresikan melalui floem di akar ke tanah.

$$
\text { Berdasarkan data hasil }
$$

pengukuran kandungan logam berat kadmium menunjukkan penyerapan logam terdistribusi dari akar ke bagian batang tumbuhan terutama ke bagian daun. Menurut Amin, et .al. (2011) melalui akar mangrove Avicennia sp. dapat menyerap logam-logam yang terdapat dalam sedimen dan kolom air bersama-sama dengan nutrien lain kemudian didistribusikan ke bagian lain dari tumbuhan. Menurut Fitter dan Hay (1992) yang disetir oleh Akbar, et.al., (2015) salah satu cara pergerakan ion ke arah tanaman yaitu dengan aliran massa dalam air bergerak masuk menuju ke akar. Menurut Mac Farlane et.al., (2003) akar Avicennia sp. dapat dijadikan indikator biologis paparan lingkungan yang terkontaminasi dengan logam kadmium. Menurut Hamzah dan Setiawan (2010) yang disetir oleh Setiawan (2013) mangrove Avicennia sp. mempunyai kemampuan mengkumulasi logam lebih tinggi 
dibandingkan dengan Rhizophora sp. Menurut McFarlane, et .al. (2003) Rhizophora sp. tergolong rendah dalam mengakumulasi logam. Menurut Connel dan Miller (2006) yang disetir oleh Supriyantini, et al. (2017) bioakumulasi merupakan suatu proses peningkatan konsentrasi logam berat di tubuh oleh organisme. Berdasarkan data hasil penelitian maka dapat dikatakan mangrove Avicennia sp. sangat potensi sebagai spesies fitoremediator untuk ekosistem mangrove.

Menurut Chaney, et.al. (1998) yang disetir oleh Munthe, et. al. (2016) logam berat akan didistribusikan ke seluruh jaringan tanaman melalui jaringan sampai ke daun melalui proses uptake pada akar dan dilepas ke lingkungan melalui proses respirasi daun. Rendahnya kandungan logam yang terdapat di daun hal ini kemungkinan telah terjadi konjugasi atau kompleksitas dengan zat lain yang terdapat dalam mitokondria di daun.

Mangrove merupakan salah satu tumbuhan yang mampu hidup pada lingkungan berair terutama perairan pantai. Menurut Thampanya, et.al., (2002) hutan mangrove adalah komunitas tumbuhan vegetasi pantai yang mampu tumbuh dan berkembang di daerah pasang surut. Menurut Agustina (2014) kemampuan berbagai spesies mangrove beradaptasi dengan lingkungan basa berbeda-beda. Di daerah endapan lumpur yang terendam secara permanen didominasi oleh Rhizopora sp. sedangkan daerah yang terendam secara periodik didominasi oleh Avicennia sp. Mulyadi (2009) menyatakan bahwa mangrove sebagai penampungan limbah terakhir yang berasal dari aktivitas manusia melalui aliran sungai menuju ke muara sehingga daerah ekosistem mangrove merupakan daerah penumpukan limbah yang masuk ke lingkungan estuari.

\section{KESIMPULAN}

Berdasarkan hasil penelitan dilakukan maka diperoleh beberapa kesimpulan sebagai berikut akumulasi kandungan kadmium tertinggi terdapat pada jenis mangrove Avicennia sp. yaitu pada bagian akar, dibandingkan dengan jenis mangrove Rhizophora sp. Empat lokasi penelitian kandungan logam kadmium tertinggi terdapat di Desa Ambon Likupang pada mangrove Avicennia sp. yaitu 44.355 ppb. Berdasarkan data analisis logam kadmium di empat lokasi penelitian, dapat dikatakan bahwa logam tersebut sangat tinggi, hal ini dibandingkan dengan baku mutu kadmium pada biota laut yaitu $0,001 \mathrm{mg} / \mathrm{L}$ menurut KEPMEN LH NO. 51. Tahun 2004.

\section{SARAN}

\begin{tabular}{|c|c|}
\hline 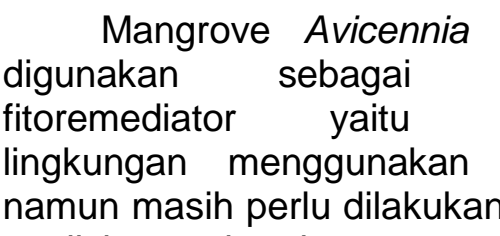 & $\begin{array}{l}\text { sp. dapat } \\
\text { tumbuhan } \\
\text { pemulihan } \\
\text { tumbuhan } \\
\text { n penelitian }\end{array}$ \\
\hline $\begin{array}{l}\text { analisis } \\
\text { kandungan } \\
\text { kadungan } \\
\text { sebagai pembanding. }\end{array}$ & $\begin{array}{l}\text { akumulasi } \\
\text { sedimen }\end{array}$ \\
\hline
\end{tabular}

\section{DAFTAR PUSTAKA}

Agustina, S. 2014. Mangrove Sebagai Pengendali Pencemar Logam Berat. Program Studi Manajemen Sumberdaya Perikanan Universitas Gadjah Mada. Yogyakarta

Akbar, Syarifuddin, L., Maming. 2015. Analisis Logam Berat Timbal(Pb) dan Kadmium (Cd) pada akar, kulit batang, daun mangrove (Avicennia marine) dan sedimen, Tanjung Bunga Makassar. Jurusan Kimia FMIPA Universitas Hasanuddin. Makassar.

Amin, B., Afriyani, E., Saputri, A. M., 2011, Distribusi spasial logam $\mathrm{Pb}$ dan $\mathrm{Cu}$ pada sedimen dan air laut Permukaan 
di perairan Tanjung Buton Kabupaten Siak Provinsi Riau. Jurnal Teknobiologi, 2(1), 1-8.

Atdjas, Dorce. 2008. Dampak Kadar Cadmium (Cd) dalam Tubuh Kerang Hijau (Perna viridis) di Daerah Tambak Muara Karang Teluk Jakarta Terhadap Kesehatan Manusia.

Darmono. 2001. Lingkungan Hidup dan Pencemaran (Hubungannya dengan Toksikologi Senyawa Logam). Penerbit : Universitas Indonesia. Press: Jakarta.

Deri., Emiyarti, La Ode, A. A. 2013. Heavy Metal Acumulattion of Lead $(\mathrm{Pb})$ of Mangrove Avicennia marina Roots in Kendari Bay. Jurnal Mina Laut Indonesia, 1\{1\}:38- 40.

Fitter, A.H.,Hay, R.K.M. 1991. Fisiologi Lingkungan Tanaman. Gajah Mada University Press: Yogyakarta.

Hardiani, H. 2009. Potensi Tanaman dalam Mengakumulasi Logam Cu Pada Media Tanah Terkontaminasi Limbah Padat Industri Kertas.

Jupriyati, R., Soenardjo N., Adhi C. S. 2013. Akumulasi Logam Berat Timbal (Pb) dan Pengaruhnya Terhadap Histologi Akar Mangrove Avicennia marina (Forssk). Vierh. di Perairan Mangunharjo Semarang. Journal Of Marine Research. Volume 3 Nomor 1 Halaman 6168. Program Studi IImu Kelautan, Fakultas Perikanan dan IImu Kelautan, Universitas Diponegoro. Semarang.

Kawung, N. J. Mangindaan, R.E.P. , Rompas, R.M., Chasanah, E., Januar, H.I., Fajarningsih, D., Sumangando, A. 2016. Impact On Increasing Anthropogenic Pressure To The Variability Of Cembranoid Compounds
Derived Of Softcoral Sinularia Sp From Manado The Waters And Their Antitumor Activity. International Journal of Information Research and Revie, . 03\{12\}:3304-3308,

Kristanti, R. A., Mursidi, Sarwono. 2007. Kandungan Beberapa Logam Berat Pada Bakau (Rhizophora apiculata) di Perairan Bontang Selatan, Kalimantan Timur. Kalimantan.

Lakitan, B. 2000. Dasar-dasar Fisiologi Tumbuhan. PT. Raja Grafindo Persada, Jakarta. 204 hal.

McFarlane, Pulkownik,G.R.A., Burchet. 2003 Accumulation. and distribution of heavy metals in $t$ he grey mangrove Avicennia marina (Forsk.)123 : 139-151.

Mamoribo, Rompas., R., Kalesaran, O.J. 2015. Determinasi Kandungan Kadmium (Cd) di Perairan Pantai Malalayang Sekitar Rumah Sakit Prof Kandou Manado. Jurnal Budidaya Perairan ,3[1]: 14-118.

Mulyadi, E., Laksmono, R., Aprianti, D., 2009. Fungsi Mangrove Sebagai Pengendali Pencemar Logam Berat. Jurnal IImiah Teknik Lingkungan, 1:33-40.

Munthe H. K., Yunasfi, Suryanti, A. 2007. Bioakumulasi Logam Berat Kadmium (Cd) pada Akar Kulit Batang dan Daun Avicennia marina di Kawasan Mangrove Percut Sei Tuan Kabupaten Deli Serdang Sumatera Utara. Fakultas Pertanian, Universitas Sumatera Utara. Medan.

Paruntu C. P., Windarto A. B. Rumengan A. P. 2017. Karakteristik Komunitas Mangrove Desa Motandoi Kecamatan Pinolosian Timur 


$\begin{array}{lr}\text { Kabupaten } & \text { Bolaang } \\ \text { Mongondow Selatan Provinsi } \\ \text { Sulawesi Utara. Jurnal Pesisir } \\ \text { dan Laut Tropis Volume } 1 \\ \text { Nomor 2 Tahun 2017. Fakultas } \\ \text { Perikanan dan Ilmu Kelautan } \\ \text { Unsrat Universitas Sam } \\ \text { Ratulangi. Manado. }\end{array}$

Paulus. 2017. Serangga Issidae pada Mangrove Sebagai Bioindikator Logam Cadmium. Manado. 104 hal.

Parvaresh, H. Z., Abedi P., Farhchi M., Karami N., Khorasan, Karbassi A. 2010. Bioavalabilityand Concentration of Heavy Metals in the Sediments and Leaves of Grey Mangrove, Avicennia marina (Forsk.) Vierh, in Sirik Azini Creek, Iran, Biol. Trace Elem. Res. DOI.10 1007 /s 12011-010-8891-y

Petrucci, R.H. 1987. Kimia Dasar Prinsip dan Terapan Modern Jilid $1 . \quad$ Erlangga. Jakarta.

Prasad, M. K., Ramanathan, A. L. 2008. Sedimentary Nutrien Dynamics in ATropical Estuarine Mangrove Ecosistem. Estuarine, Coastal and Shelf. Science Journal. 80:60-66.

Widowati, W. 2008. Efek Toksik Logam Pencegahan dan Penanggulangan Pencemaran. Yogyakarta: Penerbit Andi.

Puwiyanto, A. I. S. 2013. Daya Serap Akar dan Daun Mangrove Terhadap Logam Tembaga (Cu) diTanjung Api-Api. Program Studi IImu Kelautan, Fakultas Matematika dan IImu Pengetahuan Alam Universitas Sriwijaya. Sumatera Selatan.

Rompas, R. M. 1997. Dasar-dasar Toksikologi. FPIK. Manado.

Rompas, R. M. 2011. Toksikologi Kelautan. Sekretaris Dewan Kelautan Indonesia. Jakarta. 338h.

Setiawan, H. 2013. Akumulasi dan Distribusi Logam Berat pada Vegetasi Mangrove di Perairan Pesisir Sulawesi Selatan. Jur. IImu Kehutanan. Vol.VII. No.1

Supriyantini, E., R. Azizah, C.P. Dewi. 2017. Daya Serap Mangrover Rhizophora sp. Terhadap Logam Berat Timbal (Pb) di Perairan Mangrove Park, Pekalongan.

Thampanya, U., Vermaat, J. E., Terrados. 2002. The Effect of Increasing Sediment Accretion on the Seedlings of Three Common Thai Mangrove Species. Aquaric Botany, 74:315-325.

Tilaar, S. 2014. Analysis of Heavy Metal Polution In River Mouths And Estuaries Tondano And Sario in Manado City North Sulawesi. Jurnal IImiah Platax Vol. 2:(1). 